\title{
Article
}

\section{Corneal Penetration of Low-Dose Atropine Eye Drops}

\author{
Henning Austermann ${ }^{1}$, Frank Schaeffel ${ }^{1,2}$, Ute Mathis ${ }^{1}$, Verena Hund ${ }^{3}$, Frank Mußhoff ${ }^{4}\left(\right.$, Focke Ziemssen ${ }^{1, *}(\mathbb{C})$ \\ and Sven Schnichels ${ }^{1}$ \\ 1 Center for Ophthalmology, Eberhard Karls University, 72076 Tübingen, Germany; \\ henning.austermann@hotmail.de (H.A.); frank.schaeffel@uni-tuebingen.de (F.S.); \\ ute.mathis@uni-tuebingen.de (U.M.); sven.schnichels@med.uni-tuebingen.de (S.S.) \\ 2 IOB Clinical Research Center, Myopia Research Group, CH-4031 Basel, Switzerland \\ 3 Hospital Pharmacy, University Hospital Tübingen, 72076 Tübingen, Germany; \\ verena.hund@med.uni-tuebingen.de \\ 4 Forensic Toxicological Center GmbH, 80335 Munich, Germany; f.musshoff@ftc-muenchen.de \\ * Correspondence: focke.ziemssen@med.uni-tuebingen.de; Tel.: +49-(0)7071-29-88088; Fax: +49-(0)7071-29-4674
}

check for updates

Citation: Austermann, H.; Schaeffel, F.; Mathis, U.; Hund, V.; Mußhoff, F.; Ziemssen, F.; Schnichels, S. Corneal Penetration of Low-Dose Atropine Eye Drops. J. Clin. Med. 2021, 10, 588. https://doi.org/10.3390/jcm 10040588

Academic Editor: António Queirós Pereira

Received: 28 December 2020

Accepted: 1 February 2021

Published: 4 February 2021

Publisher's Note: MDPI stays neutral with regard to jurisdictional claims in published maps and institutional affiliations.

\begin{abstract}
Major studies demonstrating the inhibition of myopia in children and juveniles by low-dose atropine eye drops provide little information on the manufacturing process and the exact composition of the atropine dilutions. However, corneal penetration might significantly vary depending on preservatives, such as benzalkonium chloride (BAC), and the atropine concentration. Since there is a trade-off between side effects, stability, and optimal effects of atropine on myopia, it is important to gain better knowledge about intraocular atropine concentrations. We performed an ex vivo study to determine corneal penetration for different formulations. Atropine drops $(0.01 \%)$ of different formulations were obtained from pharmacies and applied to the cornea of freshly enucleated pig eyes. After $10 \mathrm{~min}$, a sample of aqueous humor was taken and atropine concentrations were determined after liquid-liquid extraction followed by high-performance liquid chromatographytandem mass spectrometry (LC-MS/MS). The variability that originated from variations in applied drop size exceeded the differences between preserved and preservative-free formulations. The atropine concentration in the anterior chamber measured after $10 \mathrm{~min}$ was only $3.8 \times 10^{-8}$ of its concentration in the applied eye drops, corresponding to $502.4 \mathrm{pM}$. Obviously, the preservative did not facilitate corneal penetration, at least ex vivo. In the aqueous humor of children's eyes, similar concentrations, including higher variability, may be expected in the lower therapeutic window of pharmacodynamic action.
\end{abstract}

Keywords: low-dose atropine; myopia; ocular pharmacokinetics

\section{Introduction}

According to meta-analyses, Cochrane reviews, and health technology assessments (HTAs), there is a large body of evidence that low-dose $(0.01 \%)$ atropine is effective in reducing increases in childhood myopia [1-5]. The efficacy of the topical administration of atropine drops to control myopia has been known for almost 150 years [6]. In spite of their effectiveness in slowing axial elongation, the use of commercially available and higherconcentration atropine $(0.1 \%, 0.5 \%$, and $1 \%)$ is not well-accepted due to concentrationdependent side effects, including light sensitivity, reduced near vision, and a significant rebound effect after discontinuation. Therefore, off-label treatment with low-dose atropine is widely used in order to slow down the progression typically seen at school age.

Fine control of eye-length growth is largely achieved by image processing in the retina [7], without the need for central/cortical visual processing. The exact mechanism is still a subject of ongoing speculation and investigation [8,9]. In addition to the potential impact of accompanying substances, a very small amount of atropine broad-spectrum muscarinic acetylcholine receptor $(\mathrm{mAChR})$ antagonist on the retina might be sufficient to cause regulatory changes [10]. Binding data and characteristics for muscarinic receptor 
antagonists have been published [11]. Dopamine (DA) and nitric oxide (NO) have been implicated in the process of myopia inhibition. However, some very potent $\mathrm{mAChR}$ antagonists (QNB (quinuclidinyl benzilate), dicyclomine, scopolamine, tropicamide) showed little effect in the chick model [12], and no link was identified between any mAChR genes and the risk of increased myopia [12].

Despite a consensus on basic efficacy, there is an ongoing debate about the duration and dosage of low-dose atropine [13,14]. A group from Rotterdam still promotes the use of $0.5 \%$ (or even $1 \%$ ) atropine [15], while prescribing photochromatic multifocal glasses to reduce the photophobia secondary to dilated pupils. The large ATOM 2 study (400 children randomized in Singapore) reported a more favorable effect (less rebound, fewer side effects) of the lower dose [16]; however, a generally accepted standard of judging the effect primarily by the objective axis length has not yet been consistently achieved [17,18]. A recent randomized trial (LAMP study) reported the effective performance of other low concentrations $(0.025 \%, 0.05 \%)$ of atropine eye drops over two years [19]. Although a concentration-dependent response seems reasonable [20], these data (a non-significant slowing of axial elongation for $0.01 \%$ atropine over 24 months) contradict previous studies and only reflect experience over two years. While other physicians have tested the daily use of a $0.02 \%$ concentration [21], $0.01 \%$ atropine is currently the most commonly used and investigated agent in the United States, East Asia, and Europe [22-25].

Unfortunately, most publications are very brief or do not specify exactly which formulations of atropine were used [16,19]. Most colleagues will use some sort of dilution of the $0.5 \%$ atropine eye drops used diagnostically. Dutch colleagues have indicated the ingredients of the drops they prescribe: benzalkonium chloride (BAC) as preservative, sodium edetate, boric acid, and purified water. The stability of atropine depends on the formulation [26]. Although the bioavailability and intraocular pharmacokinetics of atropine are well characterized [27], little is known about its precise penetration of the cornea. If we hypothetically assume a retinal concentration of $100 \mathrm{mM}$ atropine $(60 \mu \mathrm{M}-6 \mathrm{mM})$, this would still be much greater than the affinity of atropine at the M4 receptor $\left(\mathrm{K}_{\mathrm{d}}=180 \mathrm{pM}\right)$ [11]. With increasing levels, an increasing probability of off-target effects must also be assumed [28]. It has been speculated that, in addition to the retina, scleral fibroblasts may also be involved [29,30], or, more unlikely, the corneal endothelium [31]. It was identified early that pharmacodynamic effects also depend on iris pigmentation: mydriasis lasted significantly longer in pigmented animals (half-life $96 \mathrm{~h}$ vs. $43 \mathrm{~h}$ in pigmented vs. albino animals) [32]. Further studies have confirmed that that melanin binding of atropine caused prolonged action [33].

Especially considering the world-wide growth of prescriptions [14], we were interested in the impact of different formulations, the drop-to-drop variability, and the potential influence of preservatives such as BAC in the formulations. These questions should be investigated in simple, well-standardized ex vivo models to exclude other confounding factors as much as possible [34].

\section{Materials and Methods}

Freshly enucleated pig eyes were directly transferred to the laboratory on ice. Because they originated from a slaughterhouse (Emil Färber GmbH \& Co. KG, Balingen, Germany), a separate animal experiment application was not required, in accordance with good laboratory practice. In an established set-up, the eyes were first checked for gross defects and then rinsed in a Tris-buffered saline (TBS). The globes were fixated with the cornea facing upwards. The eyes were moistened again with TBS buffer for about $30-45 \mathrm{~s}$ before application of the eye drops. We applied $40 \mu \mathrm{L}$ of the drops to the cornea by pipette [35,36]. Drainage of the drops was not obstructed, resulting in additional contact of the drops with the sclera. This resembles a real-life situation and was performed in the same manner for all formulations. The eyes were received from the abattoir mostly without conjunctiva. For consistency, all external tissue was removed before drop application. After an incubation time of $10 \mathrm{~min}$, a $200 \mu \mathrm{L}$ sample of the aqueous humor was collected with a $1 \mathrm{~mL} \mathrm{Tbc}$ 
syringe and a $30 \mathrm{G}$ cannula. The samples were frozen at $-80{ }^{\circ} \mathrm{C}$ for further analysis [37]. During a preliminary experiment, which corresponded to phase $\mathrm{I}(n=6)$, the variability of the measurement method and the experimental setup was determined $( \pm 227 \mathrm{pg} / \mathrm{mL})$. Based on an effect size of 1.4, the sample size was calculated to be 12 per group, using the two-sample mean calculator for mean difference to test the significance between the two groups ( $a=0.05,1-b=0.9,2$-tailed). A Wilcoxon signed-rank test was used to compare distributions for non-normally distributed data. For data analysis, the statistical software package JMP V.14.2.0 (SAS Institute, Cary, NC, USA) was used.

\subsection{Liquid Chromatography}

Determination was performed after liquid-liquid extraction followed by highperformance liquid chromatography-tandem mass spectrometry (LC-MS/MS) [27]. The processing of the thawed samples included work-up of $50 \mu \mathrm{L}$ of the aqueous humor sample with $50 \mu \mathrm{L} 0.9 \% \mathrm{NaCl}, 2 \mu \mathrm{L}$ internal standard, and $100 \mu \mathrm{L}$ buffer $(5 \mathrm{mM}$ ammonium formiate in water:methanol $(85: 15, V / V))$. Potash lye was contained in the solvent $(0 ; 0.05$; $0.1 ; 0.25 ; 0.5 ; 1.25 ; 2.5 ; 5 \mathrm{ng} / \mathrm{mL})$. The dilution factor was considered in the final result. After vortexing and centrifugation, $1 \mu \mathrm{L}$ was directly injected into the LC-MS/MS system (Agilent Technologies 1290 Infinity with Sciex QTrap 6500, Agilent, Santa Clara, CA, USA). Separation was performed with a Kinetex $2.6 \mu \mathrm{m}$ Biphenyl $100 \AA$, $50 \mathrm{~mm} \times 2.1 \mathrm{~mm}$ (Phenomenex, Aschaffenburg, Germany), operating at $30^{\circ} \mathrm{C}$ under gradient conditions for $7 \mathrm{~min}$, with a flow rate of $0.5 \mathrm{~mL} / \mathrm{min}$, using eluents A $(5 \mathrm{mM}$ ammonium formiate in $0.1 \%$ formic acid in water) and B ( $5 \mathrm{mM}$ ammonium formiate in $0.01 \%$ formic acid in methanol; positive electrospray ionization $(5 \mathrm{kV}), 555^{\circ} \mathrm{C}$, and MRM (multiple reaction monitoring) mode with three transitions). The gradient was as follows: it started at $5 \% \mathrm{~B}$, followed by an increase to $75 \%$ B from 1.0 to $5.0 \mathrm{~min}$. After rising to $100 \% \mathrm{~B}$ in $0.5 \mathrm{~min}$, the gradient was held from $5.5 \mathrm{~min}$ to $6.5 \mathrm{~min}$. Finally, gradient B was decreased to $5 \%$ at $7 \mathrm{~min}$.

In accordance with good laboratory practice (GCP), the determination was made after regular calibration in the range of $0.05-100 \mathrm{ng} / \mathrm{mL}$, with appropriate internal standards and controls. The lower limit of detection (LLOD) of the LC-MS/MS assay was $0.03 \mathrm{ng} / \mathrm{mL}$, and the lower limit of quantification (LLOQ) $0.05 \mathrm{ng} / \mathrm{mL}$. Precision was determined within $6.9 \%$.

\subsection{Atropine Preparations}

The different preparations were obtained from pharmacies (Table 1). The pharmacies (Alte Apotheke, Stuttgart, Germany; Berg-Apotheke, Tecklenburg, Germany) did not know about the analysis. One unpreserved preparation corresponded to the study medication of an ongoing safety study (EUDRACT 2017-002588-17, Pharma Stulln, Stulln, Germany). Atropine POS 0.5\% (0.2 mL; URSAPHARM, Saarbrücken, Germany) contains $5.0 \mathrm{mg}$ of atropine sulphate and $0.50 \mathrm{mg}$ BAC (benzalkonium chloride) per $10 \mathrm{~mL}$, corresponding to $0.05 \mathrm{mg} / \mathrm{mL}$. The approved medication is used to eliminate accommodation for diagnostic purposes (e.g., for pre-treatment for refraction determination or funduscopy; for penalization when occlusion treatment is not possible; to relieve accommodation spasms in hyperopia; in acute and chronic intraocular inflammations; in cases of injury to the iris or pupil; in ciliary body detachment; in cases of ciliolenticular block; or for disruption of synechiae).

In addition, atropine formulations of different concentrations were freshly prepared by the university pharmacy. The concentration of the preparations used was also controlled by means of LC-MS/MS. A balanced salt solution (BSS) served as a negative control without any atropine. 
Table 1. Overview of tested formulations.

\begin{tabular}{|c|c|c|c|c|c|}
\hline Formulation & Ingredients & Volume & $\begin{array}{l}\text { Instructions for Use } \\
\text { (Technical Information) }\end{array}$ & Shelf Life & Pharmacy \\
\hline $0.01 \% \mathrm{~F} 1$ & $\begin{array}{l}\text { Atropine sulphate } 0.1 \mathrm{~g} / \mathrm{g}, \\
\text { benzalkonium chloride } 0.005 \% \text {, } \\
\text { sodium chloride, water }\end{array}$ & $10 \mathrm{~mL}$ & $\begin{array}{c}\text { Storage at } 15-25^{\circ} \mathrm{C} \\
\text { Can be used for } 4 \text { weeks } \\
\text { after opening. }\end{array}$ & 12 months & Bergapotheke \\
\hline $0.01 \% \mathrm{~F} 2$ & $\begin{array}{l}\text { Atropine sulphate } 0.01 \% \text {, } \\
\text { benzalkonium chloride } 0.005 \% \text {, } \\
\text { sodium chloride } 0.9 \% \text {, } \\
\text { water for injection }\end{array}$ & $10 \mathrm{~mL}$ & $\begin{array}{l}\text { Keep protected from children } \\
\text { Can be used for } 4 \text { weeks } \\
\text { after opening. }\end{array}$ & 8 months & Alte Apotheke \\
\hline $0.01 \%$ F3 & $\begin{array}{l}\text { Atropine sulphate } 0.1 \mathrm{mg}, \\
\text { sodium chloride, } \\
\text { sodium edetate, } \\
\text { preserved with } 0.005 \% \\
\text { benzalkonium chloride }\end{array}$ & $10 \mathrm{~mL}$ & $\begin{array}{c}\text { Store below } 25^{\circ} \mathrm{C} \\
\text { Can be used for } 4 \text { weeks } \\
\text { after opening. }\end{array}$ & 8 months & $\begin{array}{l}\text { University } \\
\text { Pharmacy }\end{array}$ \\
\hline $0.01 \%$ PF1 & $\begin{array}{l}\text { Atropine sulphate } 0.1 \mathrm{mg}, \\
\text { sodium chloride, } \\
\text { hydrochlorid acid, } \\
\text { water for injection }\end{array}$ & $0.5 \mathrm{~mL}$ & $\begin{array}{l}\text { For single use. } \\
\text { Discard the rest! } \\
\text { Store at } 15-25^{\circ} \mathrm{C} \text {. }\end{array}$ & 12 months & Bergapotheke \\
\hline $0.01 \%$ PF2 & $\begin{array}{l}\text { Atropine sulphate } 0.1 \mathrm{mg}, \\
\text { sodium chloride, } \\
\text { hydrochlorid acid, } \\
\text { water for injection }\end{array}$ & $10 \mathrm{~mL}$ & $\begin{array}{c}\text { Store below } 25^{\circ} \mathrm{C} \text {. Use } 24 \mathrm{~h} \\
\text { after opening. }\end{array}$ & 1 month & $\begin{array}{l}\text { University } \\
\text { Pharmacy }\end{array}$ \\
\hline $0.01 \% \mathrm{PF} 3$ & Atropine sulphate $0.1 \mathrm{mg}$ n.d. & $0.25 \mathrm{~mL}$ & $\begin{array}{l}\text { Store in refrigerator } 2-8^{\circ} \mathrm{C} \text {. } \\
\text { After opening the sachet, the } \\
\text { contents of the intact } \\
\text { single-dose containers can be } \\
\text { used for } 1 \text { month. }\end{array}$ & 3 months & $\begin{array}{l}\text { Study } \\
\text { Medication }\end{array}$ \\
\hline $0.1 \%$ & $\begin{array}{l}\text { Atropine sulphate } 1 \mathrm{mg}, \\
\text { sodium chloride, } \\
\text { sodium edetate, } \\
\text { preserved with } 0.005 \% \\
\text { benzalkonium chloride }\end{array}$ & $10 \mathrm{~mL}$ & $\begin{array}{c}\text { Store below } 25^{\circ} \mathrm{C} \\
\text { Can be used for } 4 \text { weeks } \\
\text { after opening. }\end{array}$ & 8 months & $\begin{array}{l}\text { University } \\
\text { Pharmacy }\end{array}$ \\
\hline $0.5 \%$ & $\begin{array}{l}\text { Atropine sulphate } 5 \mathrm{mg} / \mathrm{mL} \text {, } \\
\text { benzalkonium chloride } \\
0.05 \mathrm{mg} / \mathrm{mL}, \\
\text { sodium chloride, water }\end{array}$ & $10 \mathrm{~mL}$ & $\begin{array}{l}\text { Do not store above } 25^{\circ} \mathrm{C} \text {. } \\
\text { Use } 4 \text { weeks after opening. }\end{array}$ & 18 months & Ursapharm \\
\hline
\end{tabular}

$\mathrm{F}$, formulation, $\mathrm{PF}$, preserved formulation, n.d., not defined.

\section{Results}

Verification of the atropine concentration confirmed that the examined preparations contained a mean deviation of less than $12 \%$ from the declared concentration $(95 \% \mathrm{CI}$ (confidence interval): $92.5-113.2 \%$ ). The standard error of the mean (SEM) was between $67.1 \mathrm{pg} / \mathrm{mL}$ and $119.7 \mathrm{pg} / \mathrm{mL}$ for all $0.01 \%$ formulations; the measurement variability was greatest for the $0.5 \%$ atropine (SEM $4.5 \mathrm{ng} / \mathrm{mL}, n=12$ ).

For three different formulations without preservatives, a concentration of atropine sulphate in the anterior chamber of $340.9 \mathrm{pg} / \mathrm{mL}$ was found (Figure 1; formulation 1: $322.3 \mathrm{pg} / \mathrm{mL}$, formulation 2: $405.0 \mathrm{pg} / \mathrm{mL}$, formulation 3: $300.7 \mathrm{pg} / \mathrm{mL}$ ). Thus, the median proportion of the penetrated active ingredient detected in the aqueous humor $10 \mathrm{~min}$ after application was 1:3 $\times 10^{7}$. No atropine was measured in the control eyes.

The penetration of the preparations with preservative did not differ significantly from the preservative-free eye drops (Wilcoxon signed-rank test, $p=0.387$ ). The mean concentration in the anterior chamber was $418.3 \mathrm{pg} / \mathrm{mL}$ for the three BAC formulations $(284.8 \mathrm{pg} / \mathrm{mL}, 530.5 \mathrm{pg} / \mathrm{mL}, 429.4 \mathrm{pg} / \mathrm{mL})$.

There was a clear dose-dependent increase of detected atropine sulphate in the aqueous humor (Figure 2). The mean level in the anterior chamber was $0.4 \mathrm{ng} / \mathrm{mL}(95 \%$ CI: $299-459 \mathrm{pg} / \mathrm{mL}), 4.7 \mathrm{ng} / \mathrm{mL}(95 \%-C I: 2.8-6.7 \mathrm{ng} / \mathrm{mL})$, and $14.6 \mathrm{ng} / \mathrm{mL}(95 \%-C I$ : $3.6-25.6 \mathrm{ng} / \mathrm{mL}) 10 \mathrm{~min}$ after administering $0.01 \%, 0.1 \%$, and $0.5 \%$ eye drops. Although the fluctuations were clearly greatest with the highest concentration applied, the median per- 
centage of the penetrated drug tended to be stable, $0.0000031 \%, 0.0000038 \%$, and $0.0000017 \%$ of the actual quantity measured in the bottle. Compared to the nominally reported concentration, only a very small amount was found in the aqueous humor: 1:31115933 (dilution by $3.8 \times 10^{-8}$ for $0.01 \%$ ), 1:2136494 (dilution by $4.7 \times 10^{-7}$ for $0.1 \%$ ), and 1:104298 (dilution by $4.9 \times 10^{-7}$ for $\left.0.5 \%\right)$.

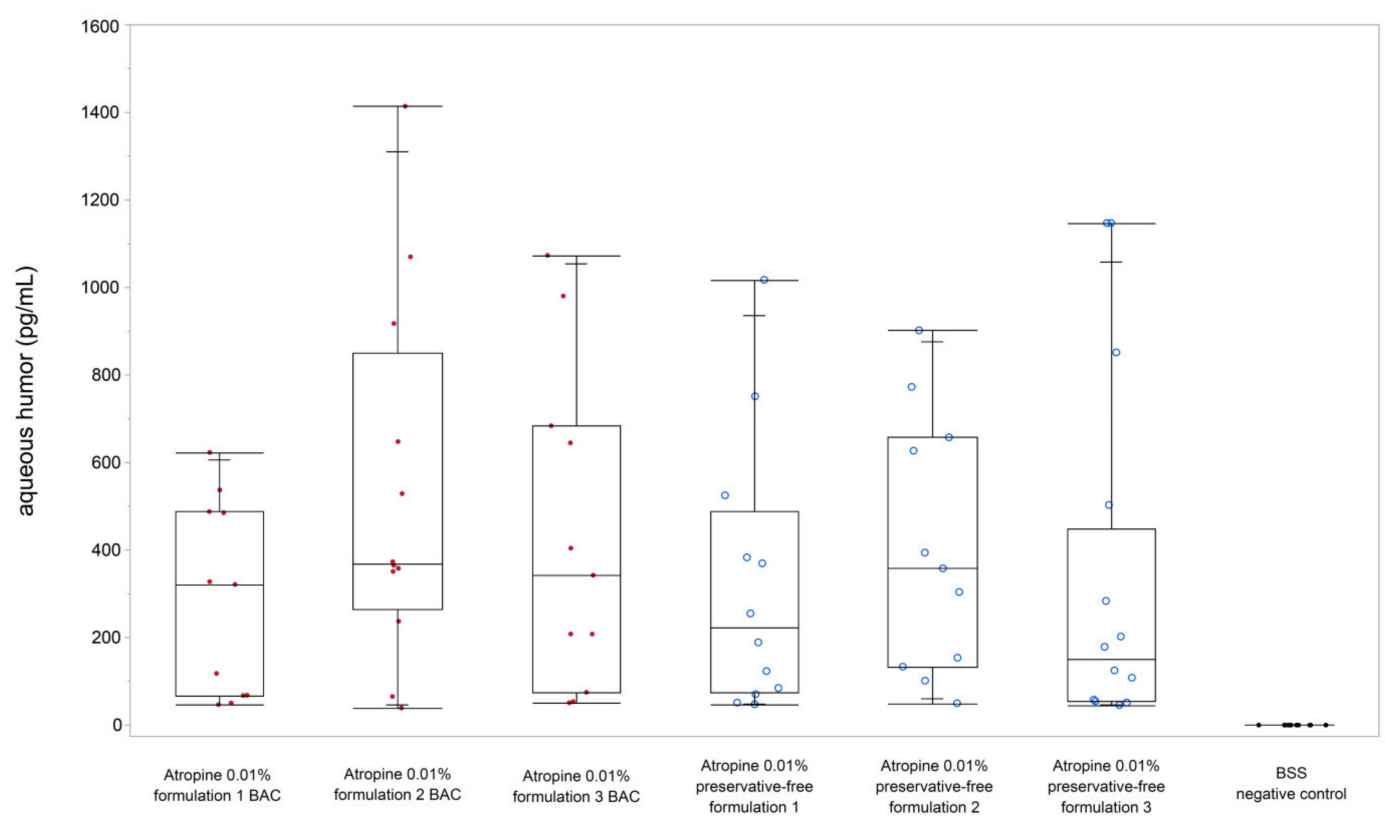

Figure 1. Concentration of atropine sulphate in aqueous humor for atropine $0.01 \%$ formulation with BAC (red) vs. preservative-free formulations. The bars within the box plots represent the median values, the edges represent the 25 th $/ 75$ th percentiles, and the whiskers extend from the ends of the boxes to the outermost data points within the quartile- $-1.5 \times$ of the interquartile range.

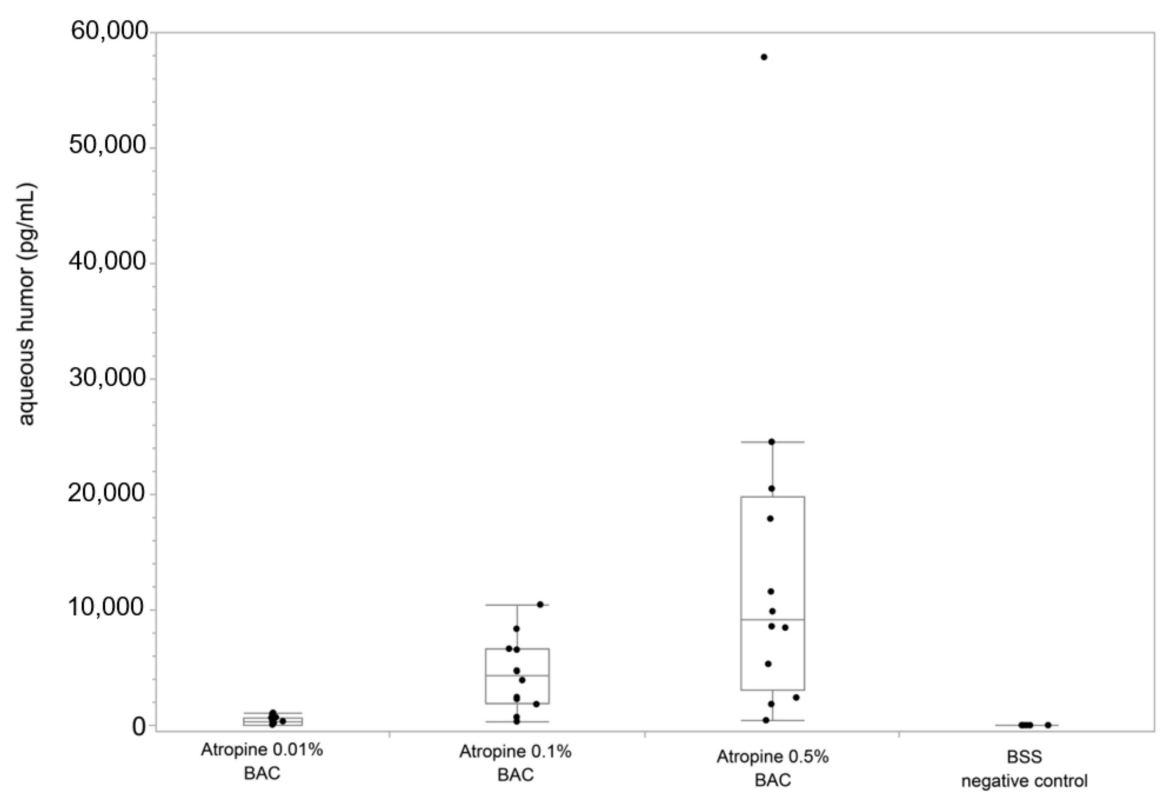

Figure 2. Concentration of atropine sulphate in aqueous humor for different atropine concentrations $(0.01 \%, 0.1 \%, 0.5 \%$, all including BAC). The bars within the box plots represent the medians, the edges represent the 25th/75th percentiles, and the whiskers extend from the ends of the box to the outermost data points within the quartile- $1.5 \times$ of the interquartile range. 
In the short follow-up period, the eyes showed no microscopically visible differences (stainability of the epithelium).

\section{Discussion}

While the majority of randomized trials (ATOM 2, LAMP) have not reported on the presence or precise concentrations of the preservatives/ingredients [16,19], recent trials provided specific measures within the study protocol, such as discarding opened drop vials after one week due to the dilution of BAC [38]. Only very few studies truly looked into chemical stability and microbiological safety, despite widespread use of the treatment $[39,40]$. Although our measurements do not allow any direct conclusions to be drawn about efficacy, nor therefore about the relevant minimum concentration that would be sensible to use, it can be stated that the presence of the preservative had only a negligible effect on the penetration of a single drop.

With regards to the pharmacokinetics after instillation, the tear concentration usually falls rapidly [41]; significant drug is transferred to the cornea, while the tear concentration remains higher than the corneal concentration. The cornea can serve as a storage depot for the aqueous humor. The rate of ocular drug movement is directly proportional to the concentration differential across the barrier changes; the passive diffusion of molecules across a non-saturated barrier generally adheres to first-order kinetics. Nevertheless, it is important to note that ultimately, bioavailability (which is the amount of the drug present at the desired receptor site) is critical.

The determination of drug stability is of major concern and has been well characterized in the case of atropine. In 1975, for the first time, in the United States Pharmacopeia (U.S.P.) XIX, a monograph on stability and stability testing was published. Today, the International Conference on Harmonization (ICH) guidelines Q1A through $\mathrm{F}$ are the harmonized guidelines regarding stability studies that require marketing authorization for the European, U.S., and Japanese drug markets [42]. These clearly define that stability testing is the responsibility of the manufacturer. For off-label therapy in particular, this responsibility is transferred to the pharmacist and the prescribing physician. ICH Guideline Q1A "Stability Testing of New Drug Substances and Medicinal Products" specifies the scope of stability testing for the approval of new active substances.

Atropine is the racemized form of (S)-hyoscyamine, which occurs naturally in nightshade plants such as mandrake, angel trumpet, jimson weed, and belladonna. Only the 1:1 mixture of (R)- and (S)-hyoscyamine is called atropine. As a tropic acid ester of tropyne, atropine is susceptible to $\mathrm{pH}$-dependent hydrolysis catalyzed by both acids and bases. Kinetic studies have shown that the reaction is much slower in the acidic than in the basic environment, and therefore, the former plays only a minor role in the degradation of atropine sulfate in solution. The optimum stability of atropine with respect to hydrolysis to tropic acid is in the range of $\mathrm{pH} 3$ to 4 [43]. However, the rate of dehydration to apoatropine is greatest in that range. Starting from apoatropine, dimerization in the manner of a Diels-Alder reaction to belladonnine as well as rehydration to atropine, can occur under extreme conditions, as can proton-catalyzed hydrolytic cleavage of apoatropine to atropic acid and tropanol. The hydrolysis products of atropine are not toxic, but do not possess anticholinergic activity [44]. Differences concerning the stability of atropine solutions stored in glass, plastic, or steel were found: regarding the shelf life of storing at ambient temperatures, atropine proved to be more stable in metal than in glass or plastic cartridges [45].

Informal manufacturer queries revealed that some of the dilution protocols differed significantly. Some added $0.0245 \mathrm{~mL}$ of a $1 \%$ BAC stock solution and $4.8755 \mathrm{~mL}$ of $\mathrm{NaCl}$ $0.9 \%$ to the commercial $0.5 \%$ preparation (leading to a $\mathrm{pH}$ of 4.65 ). The degree of acidity can increase the toxicity of BAC [46]. Later, a preparation of $0.2 \mathrm{~mL} 0.5 \%$ with edetatecontaining BAC solution $0.1 \%(\mathrm{pH} 4.6)$ and $0.49 \mathrm{~g} \mathrm{NaCl} 0.9 \%$ and $10 \mathrm{~mL}$ was added to the national formulation collection (NRF 15.34, $\mathrm{pH} 4.83$ ). A formulation containing boric 
acid, thiomersal stock solution, and hypromellose was originally chosen by one pharmacy because the preservative was more effective in the $\mathrm{pH}$ range [26].

\subsection{Local Compatibility and Safety}

Allergic conjunctivitis caused by atropine instillation has been reported [47-49]. Dutch authors relate the allergic reactions to the preservative contained (0.5\%) [15]. In fact, they found more frequent reactions $(6.8 \%)$ than described in other studies of the diluted formulations.

The wide distribution of the muscarinic receptors results in a wide range of biological effects. Cai et al. suggested an effective control of epiphora with transcutaneous application of atropine gel [50]. Atropine can reduce the oversecretion of the transplanted submandibular gland by modulating aquaporin- 5 trafficking via hypersensitive $\mathrm{mAChRs}$ [51] Therefore, topical instillation might also affect lacrimal gland secretion and alter the tear film on the ocular surface. The side effects of systemic atropine are dose-dependent (accommodation, dry mouth, and urinary retention). Psychological and central nervous effects are only expected for high doses $(>10 \mathrm{mg})$ or intoxications. A paradoxical bradycardia has been described in the literature by some authors when administering intravenous doses of $0.5 \mathrm{mg}$. However, this was limited to an escalation in a very small sample of three subjects [52]. An earlier study in students observed a similar phenomenon for systemic doses of $0.25 \mathrm{mg}$ [53].

In a comparison of topical ocular drugs, atropine is generally considered to be well tolerated by the corneal epithelium: preparations of up to $1 \%$ were found to cause no epithelial damage [54]. A comparative analysis showed that there was no increase in eye pressure in the group of treated children [55]. BAC can exhibit toxic effects on the tear film and the corneal epithelium [56,57]. Early on, it was suspected that such detergents could increase drug penetration [58]. However, our studies found no evidence that this seems to play a role in this context, presumably primarily because of the dilutions used. Although BAC was reported to produce a dose-dependent arrest of cell growth and death causing necrosis at higher concentrations [59], it is unlikely for lower concentrations.

The question remains as to what precise extent continuous therapy can contribute to the risk of dry eye or a stressed surface [47]. Apart from single reports of ocular discomfort, according to the ocular surface disease index (OSDI) and the objective parameters of the tear film at break-up time, meiboscore, or the anterior segment, optical coherence tomography was not changed at all in children treated for at least six months $(n=72)$ [60]. One study found no significant differences in the amount of tear secretion or signs of ocular surface inflammation between normal healthy children $(n=38)$ and myopic children receiving topical atropine treatment $(n=126)$ [61].

\subsection{Mechanisms of Myopia Inhibition}

Myopia is the most common developmental anomaly of the human eye. Although about half of high school graduates in Germany are myopic, with a further increase to $53 \%$ among students [62], there is no consistent evidence of a significant increase in each country and, in addition, no clear proof of digital media effects [63]. Myopia-associated ocular pathology can occur irrespective of the degree of myopia (without any cut-off or threshold); however, the prevalence of sight-threatening pathology, visual burden, and optical aberrations increases with higher degrees of myopia [64]. For each individual case, the clinical significance must be challenged, parents must be informed in detail, and critical judgment must be exercised [18]. Measuring and reporting axial length should be considered important, not only in future studies [65]. Previous studies have tried to find factors that might explain the differential response to atropine [66]. However, apart from the fact that the cohorts are usually far too small to allow a multifactorial analysis of all potentially relevant parameters, it is questionable whether all influencing factors can be taken into account so easily. Apart from the known importance of behavioral change (light exposure, near work) and genetic background, adherence, pigmentation of the iris, and 
axial length would have to be considered. There is not yet a precise consensus on when to discuss which intervention to use for a given child [3].

In chickens, glucagonergic amacrine cells have been found to increase the expression of the transcription factor ZENK during positive defocus (wearing positive lenses, focal plane in front of the retina), but to decrease expression during negative defocus (wearing negative lenses, focal plane behind the retina) [8]. Besides cholinergic antagonists (both nicotinic and muscarinic), several receptor agonists and antagonists are able to suppress myopia development within these models, including dopamine agonists (apomorphine), glucagon and its agonists, retinoic acid derivatives, VIP (vasoactive intestinal peptide), and adenosine antagonists. Inhibitors of apo-lipoprotein 2 and methylxanthine (MX-7) have been shown to be effective [8], even anti-VEGF (vascular endothelial growth factor) compounds inhibit the development of deprivation myopia in chickens [67]. Originally, it was thought that myopia development was inhibited by atropine by paralyzing accommodation. However, atropine also inhibits myopia development in chickens, which lack muscarinic receptors on the ciliary muscle and therefore can accommodate normally despite atropine administration [68]. Although speculation remains as to which is the most relevant muscarinic receptor, effects have been identified at the contralateral eye even in animal models, resulting from very low systemic concentrations [69]. In addition, several muscarinic antagonists have had no effect on myopia development in chickens, so even a non-muscarinic mechanism was suspected [12]. Carr and Stell have shown that an inhibitor of the nitric oxide (NO) synthase (L-NIO) abolishes the effect of atropine on myopia and have concluded that NO mediates the effect of atropine [70]. Another mechanism could be the interaction of atropine and dopamine release [8]. While proteomic studies in retinal cells are ongoing, treatment with atropine in humans was accompanied by an increase of choroidal thickness and abolished choroidal thinning due to hyperopic defocus [71]. This is reminiscent of very similar observations in animal models: muscarinic acetylcholine agonists cause choroidal thinning in chickens, whereas antagonists cause thickening [72]. Inhibition of eye length growth is typically preceded by choroidal thickening [73,74].

The limitations of an ex vivo model, which cannot represent factors such as tear flow or turnover of the tear film, must be considered. The drop size of the dispensers was not measured, as increasing drop size does not result in the penetration of more medication into the cornea [75]. In addition, longer times for corneal penetration ( $>30 \mathrm{~min})$ have not yet been studied. However, the early examination time was to ensure that as few post-mortem changes as possible in the freshly enucleated porcine eyes (corneal epithelium, barrier disruption) had to be considered. Although species differences are unlikely given the structural homology of the cornea [34], the results cannot be extrapolated 1:1 to humans. After all, there are now numerous examples of other active ingredients whose penetration into the eye is not significantly affected by preservatives [76]. Last but not least, the size of the molecule and the concentration of the detergents are important [77]. The described variability of drug levels was found after administering similar drops (mean weight $40.3 \mathrm{mg}$, variance $0.254 \mathrm{mg}$ ). In clinical practice, the variability is certainly greater due to the dropper bottle and user.

\section{Conclusions}

Atropine $0.01 \%$ showed good, dose-dependent penetration into the cornea and anterior chamber, which was not significantly affected by additives and preservatives. Therefore, as long as long-term stability and microbiological safety are considered, appropriately unpreserved ophtioles and vials can also be used. Facing the additive effect of atropine with orthokeratology, the use of preservative-free solutions might allow a more gentle treatment, sparing the integrity of and avoiding toxicity to the corneal epithelium $[38,78,79]$.

Author Contributions: Conceptualization, H.A., F.Z. and S.S.; Methodology, H.A., F.Z. and S.S.; Validation, V.H., F.S. and F.M.; Formal Analysis, H.A. and F.M.; Investigation, V.H. and F.M.; Resources, S.S.; Data Curation, H.A., F.M. and F.Z.; Writing-Original Draft Preparation, F.Z.; Writing—Review 
and Editing, H.A., U.M., F.S. and S.S.; Visualization, F.Z. and S.S.; Supervision, S.S. All authors have read and agreed to the published version of the manuscript.

Funding: This research received no external funding.

Acknowledgments: The authors thank Katharina-Henriette Rasp, Josefine Herzog and Torsten Dame for the support of the project.

Conflicts of Interest: The authors declare no conflict of interest.

\section{References}

1. Pineles, S.L.; Kraker, R.T.; VanderVeen, D.K.; Hutchinson, A.K.; Galvin, J.A.; Wilson, L.B.; Lambert, S.R. Atropine for the prevention of myopia progression in children: A report by the American Academy of Ophthalmology. Ophthalmology 2017, 124, 1857-1866. [CrossRef]

2. Gong, Q.; Janowski, M.; Luo, M.; Wei, H.; Chen, B.; Yang, G.; Liu, L. Efficacy and adverse effects of atropine in childhood myopia: A meta-analysis. JAMA Ophthalmol. 2017, 135, 624-630. [CrossRef]

3. Prousali, E.; Haidich, A.-B.; Fontalis, A.; Ziakas, N.; Brazitikos, P.; Mataftsi, A. Efficacy and safety of interventions to control myopia progression in children: An overview of systematic reviews and meta-analyses. BMC Ophthalmol. 2019, 19, 106. [CrossRef]

4. Zhao, Y.; Feng, K.; Liu, R.-B.; Pan, J.-H.; Zhang, L.-L.; Xu, Z.-P.; Lu, X.-J. Atropine 0.01\% eye drops slow myopia progression: A systematic review and meta-analysis. Int. J. Ophthalmol. 2019, 12, 1337-1343. [CrossRef]

5. Walline, J.J.; Lindsley, K.; Vedula, S.S.; Cotter, S.A.; Mutti, D.O.; Twelker, J.D. Interventions to slow progression of myopia in children. Cochrane Database Syst. Rev. 2011, 12, CD004916. [CrossRef] [PubMed]

6. Derby, H. On the atropine treatment of acquired and progressive myopia. Trans. Am. Ophthalmol. Soc. 1874, 2, 139-154. [PubMed]

7. Sun, H.-Y.; Lu, W.-Y.; You, J.-Y.; Kuo, H.-Y. Peripheral refraction in myopic children with and without atropine usage. J. Ophthalmol. 2020, 2020, 1-10. [CrossRef] [PubMed]

8. Mathis, U.; Feldkaemper, M.; Wang, M.; Schaeffel, F. Studies on retinal mechanisms possibly related to myopia inhibition by atropine in the chicken. Graefes Arch. Clin. Exp. Ophthalmol. 2020, 258, 319-333. [CrossRef] [PubMed]

9. Upadhyay, A.; Beuerman, R.W. Biological mechanisms of atropine control of myopia. Eye Contact Lens 2020, 46, 129-135. [CrossRef] [PubMed]

10. Zhu, Y.; Bian, J.; Lu, D.; Wang, Q.; Gong, B.; Li, K.-K.; Yu, F.; Cheung, J.K.-W.; Ji, X.; Zhang, H.; et al. Combined retinal proteome datasets in response to atropine treatment using iTRAQ and SWATH-MS based proteomics approaches in guinea pig myopia model. Data Brief. 2020, 33, 106526. [CrossRef] [PubMed]

11. Carr, B.J.; Mihara, K.; Ramachandran, R.; Saifeddine, M.; Nathanson, N.M.; Stell, W.K.; Hollenberg, M.D. Myopia-inhibiting concentrations of muscarinic receptor antagonists block ac-tivation of Alpha2A-adrenoceptors in vitro. Investig. Ophthalmol. Vis. Sci. 2018, 59, 2778-2791. [CrossRef]

12. Luft, W.A.; Ming, Y.; Stell, W.K. Variable effects of previously untested muscarinic receptor antagonists on experimental myopia. Investig. Opthalmology Vis. Sci. 2003, 44, 1330-1338. [CrossRef] [PubMed]

13. Khanal, S.; Phillips, J.R. Which low-dose atropine for myopia control? Clin. Exp. Optom. 2020, 103, 230-232. [CrossRef]

14. Fang, Y.-T.; Chou, Y.-J.; Pu, C.; Lin, P.-J.; Liu, T.-L.; Huang, N.; Chou, P. Prescription of atropine eye drops among children diagnosed with myopia in Taiwan from 2000 to 2007: A nationwide study. Eye 2013, 27, 418-424. [CrossRef] [PubMed]

15. Polling, J.R.; Tan, E.; Driessen, S.; Loudon, S.E.; Wong, H.-L.; van der Schans, A.; Tideman, J.W.L.; Klaver, C.C.W. A 3-year follow-up study of atropine treatment for progressive myopia in Europeans. Eye 2020, 34, 2020-2028. [CrossRef] [PubMed]

16. Chia, A.; Chua, W.-H.; Cheung, Y.-B.; Wong, W.-L.; Lingham, A.; Fong, A.; Tan, D. Atropine for the treatment of childhood myopia: Safety and efficacy of $0.5 \%, 0.1 \%$, and $0.01 \%$ doses (atropine for the treatment of myopia 2). Ophthalmology 2012, 119, 347-354. [CrossRef]

17. Chua, W.-H.; Balakrishnan, V.; Chan, Y.-H.; Tong, L.; Ling, Y.; Quah, B.-L.; Tan, D. Atropine for the treatment of childhood myopia. Ophthalmology 2006, 113, 2285-2291. [CrossRef] [PubMed]

18. Brennan, N.A.; Toubouti, Y.M.; Cheng, X.; Bullimore, M.A. Efficacy in myopia control. Prog. Retin. Eye Res. 2020, $2020,100923$. [CrossRef] [PubMed]

19. Yam, J.C.; Li, F.F.; Zhang, X.; Tang, S.M.; Yip, B.H.K.; Kam, K.W.; Ko, S.T.; Young, A.L.; Tham, C.C.; Chen, L.J.; et al. Two-year clinical trial of the low-concentration atropine for myopia progression (LAMP) study: Phase 2 report. Ophthalmology 2020, 127, 910-919. [CrossRef]

20. Li, F.F.; Kam, K.W.; Zhang, Y.; Tang, S.M.; Young, A.L.; Chen, L.J.; Tham, C.C.; Pang, C.P.; Yam, J.C. Differential effects on ocular biometrics by $0.05 \%, 0.025 \%$, and $0.01 \%$ atropine: Low-concentration atropine for myopia progression study. Ophthalmology 2020, 127, 1603-1611. [CrossRef]

21. Lyu, Y.; Ji, N.; Fu, A.-C.; Wang, W.-Q.; Wei, L.; Qin, J.; Zhao, B.-X. Comparison of administration of $0.02 \%$ atropine and orthokeratology for myopia control. Eye Contact Lens 2020, 47, 81-85. [CrossRef]

22. Larkin, G.L.; Tahir, A.; Epley, K.D.; Beauchamp, C.L.; Tong, J.T.; Clark, R.A. Atropine 0.01\% eye drops for myopia control in american children: A multiethnic sample across three US sites. Ophthalmol. Ther. 2019, 8, 589-598. [CrossRef] 
23. Galvis, V.; Tello, A.; Parra, M.M.; Merayo-Lloves, J.; Larrea, J.; Rodriguez, C.J.; Camacho, P.A. Topical atropine in the control of myopia. Med. Hypothesis Discov. Innov. Ophthalmol. 2016, 5, 78-88. [PubMed]

24. Azuara-Blanco, A.; Logan, N.S.; Strang, N.; Saunders, K.; Allen, P.M.; Weir, R.; Doherty, P.; Adams, C.; Gardner, E.; Hogg, R.E.; et al. Low-dose $(0.01 \%)$ atropine eye-drops to reduce progression of myopia in children: A multicentre placebo-controlled randomised trial in the UK (CHAMP-UK)—Study protocol. Br. J. Ophthalmol. 2019, 104, 950-955. [CrossRef]

25. Sacchi, M.; Serafino, M.; Villani, E.; Tagliabue, E.; Luccarelli, S.; Bonsignore, F.; Nucci, P. Efficacy of atropine 0.01\% for the treatment of childhood myopia in European patients. Acta Ophthalmol. 2019, 97, e1136-e1140. [CrossRef] [PubMed]

26. Kedvessy, G.; De Grosz, S.; Szepesy, A. Preparation of ophthalmic solutions: Modern concepts: I. Atropine sulphate. Br. J. Ophthalmol. 1950, 34, 228-234. [CrossRef] [PubMed]

27. Latreille, P.-L.; Banquy, X. A simple method for the subnanomolar quantitation of seven ophthalmic drugs in the rabbit eye. Anal. Bioanal. Chem. 2015, 407, 3567-3578. [CrossRef] [PubMed]

28. Cottriall, C.; McBrien, N.; Annies, R.; Leech, E. Prevention of form-deprivation myopia with pirenzepine: A study of drug delivery and distribution. Ophthalmic Physiol. Opt. 1999, 19, 327-335. [CrossRef]

29. Barathi, V.A.; Weon, S.R.; Beuerman, R.W. Expression of muscarinic receptors in human and mouse sclera and their role in the regulation of scleral fibroblasts proliferation. Mol. Vis. 2009, 15, 1277-1293. [PubMed]

30. Hsiao, Y.-T.; Chang, W.-A.; Kuo, M.-T.; Lo, J.; Lin, H.-C.; Yen, M.-C.; Jian, S.-F.; Chen, Y.-J.; Kuo, P.-L. Systematic analysis of transcriptomic profile of the effects of low dose atropine treatment on scleral fibroblasts using next-generation sequencing and bioinformatics. Int. J. Med. Sci. 2019, 16, 1652-1667. [CrossRef]

31. Chang, W.-A.; Hsiao, Y.-T.; Lin, H.-C.; Jian, S.-F.; Chen, Y.-J.; Kuo, P.-L. Deduction of novel genes potentially involved in the effects of very low dose atropine $(0.003 \%)$ treatment on corneal epithelial cells using next-generation sequencing and bioinformatics approaches. Medicina 2019, 55, 589. [CrossRef]

32. Salazar, M.; Patil, P.N. An explanation for the long duration of mydriatic effect of atropine in eye. Investig. Ophthalmol. 1976, 15, 671-673.

33. Rimpelä, A.-K.; Reinisalo, M.; Hellinen, L.; Grazhdankin, E.; Kidron, H.; Urtti, A.; Del Amo, E.M. Implications of melanin binding in ocular drug delivery. Adv. Drug Deliv. Rev. 2018, 126, 23-43. [CrossRef]

34. Van Der Bijl, P.; Engelbrecht, A.H.; Van Eyk, A.D.; Meyer, D. Comparative permeability of human and rabbit corneas to cyclosporin and tritiated water. J. Ocul. Pharmacol. Ther. 2002, 18, 419-427. [CrossRef] [PubMed]

35. Schnichels, S.; Hurst, J.; De Vries, J.W.; Ullah, S.; Gruszka, A.; Kwak, M.; Löscher, M.; Dammeier, S.; Bartz-Schmidt, K.-U.; Spitzer, M.S.; et al. Self-assembled DNA nanoparticles loaded with travoprost for glaucoma-treatment. Nanomed. Nanotechnol. Biol. Med. 2020, 29, 102260. [CrossRef]

36. Willem de Vries, J.; Schnichels, S.; Hurst, J.; Strudel, L.; Gruszka, A.; Kwak, M.; Batz-Schmidt, K.-U.; Spitzer, M.A.; Herrmann, A. DNA nanoparticles for ophthalmic drug delivery. Biomaterials 2018, 157, 98-106. [CrossRef] [PubMed]

37. Johansen, R.; Schafer, N.C.; Brown, P.I. Effect of extreme temperatures on drugs for prehospital ACLS. Am. J. Emerg. Med. 1993, 11, 450-452. [CrossRef]

38. Kinoshita, N.; Konno, Y.; Hamada, N.; Kanda, Y.; Shimmura-Tomita, M.; Kaburaki, T.; Kakehashi, A. Efficacy of combined orthokeratology and $0.01 \%$ atropine solution for slowing axial elongation in children with myopia: A 2-year randomised trial. Sci. Rep. 2020, 10, 12750. [CrossRef] [PubMed]

39. Saito, J.; Imaizumi, H.; Yamatani, A. Physical, chemical, and microbiological stability study of diluted atropine eye drops. J. Pharm. Health Care Sci. 2019, 5, 1-6. [CrossRef]

40. Berton, B.; Chennell, P.; Yessaad, M.; Bouattour, Y.; Jouannet, M.; Wasiak, M.; Sautou, V. Stability of ophthalmic atropine solutions for child myopia control. Pharmaceutics 2020, 12, 781. [CrossRef]

41. Maurice, D.M.; Mishima, S. Ocular pharmacokinetics. Botulinum Toxin Ther. 1984, 1984, 19-116. [CrossRef]

42. Q1A(R2) Stability Testing of New Drug Substances and Products. Available online: https://www.fda.gov/regulatoryinformation/search-fda-guidance-documents/q1ar2-stability-testing-new-drug-substances-and-products (accessed on 28 December 2020).

43. Lund, W.; Waaler, T.; Meisalo, V.; Kelly, P. The kinetics of atropine and apoatropine in aqueous solutions. Acta Chem. Scand. 1968, 22, 3085-3097. [CrossRef] [PubMed]

44. Schier, J.G.; Ravikumar, P.R.; Nelson, L.S.; Heller, M.B.; Howland, M.A.; Hoffman, R.S. Preparing for chemical terrorism: Stability of injectable atropine sulfate. Acad. Emerg. Med. 2004, 11, 329-334. [CrossRef] [PubMed]

45. Zimmermann, T.; Dimmel, A.; Jüttemeyer, S.; Springer, D.; Loch, M. Rapid resolution liquid chromatography for monitoring the quality of stockpiled atropine preparations for injection. Drug Test. Anal. 2012, 4, 222-228. [CrossRef]

46. Keller, N.; Moore, D.; Carper, D.; Longwell, A. Increased corneal permeability induced by the dual effects of transient tear film acidification and exposure to benzalkonium chloride. Exp. Eye Res. 1980, 30, 203-210. [CrossRef]

47. Zhao, F.; Ma, J.-X. Will the long-term use of atropine eye drops in children increase the risk of dry eye? Med. Hypotheses 2019, 132, 109331. [CrossRef]

48. Tan, D.; Tay, S.A.; Loh, K.-L.; Chia, A. Topical atropine in the control of myopia. Asia-Pac. J. Ophthalmol. 2016, 5, 424-428. [CrossRef]

49. Kothari, M.; Jain, R.; Khadse, N.; Rathod, V.; Mutha, S. Allergic reactions to atropine eye drops for retardation of progressive myopia in children. Indian J. Ophthalmol. 2017, 66, 1446-1450. [CrossRef] [PubMed] 
50. Cai, J.R.; Shan, X.F.; Cai, Z.G.; Zhang, X.; Yu, G.Y. A new treatment for epiphora secondary to submandibular gland transplantation: Transcutaneous atropine gel. Ocul. Surf. 2014, 12, 221-226. [CrossRef]

51. Ding, C.; Cong, X.; Zhang, Y.; Yang, N.; Li, S.; Wu, L.; Yu, G. Hypersensitive mAChRs are involved in the epiphora of transplanted glands. J. Dent. Res. 2014, 93, 306-312. [CrossRef] [PubMed]

52. Boudet, J.; Qing, W.; Boyer-Chammard, A.; Del Franco, G.; Bergougnan, J.L.; Rosen, P.; Meyer, P. Dose-response effects of atropine in human volunteers. Fundam. Clin. Pharmacol. 1991, 5, 635-640. [CrossRef]

53. Lönnerholm, G.; Widerlöv, E. Effect of intravenous atropine and methylatropine on heart rate and secretion of saliva in man. Eur. J. Clin. Pharmacol. 1975, 8, 233-240. [CrossRef] [PubMed]

54. Pfister, R.R.; Burstein, N. The effects of ophthalmic drugs, vehicles, and preservatives on corneal epithelium: A scanning electron microscope study. Investig. Ophthalmol. 1976, 15, 246-259.

55. Yu, T.C.; Wu, T.E.; Wang, Y.S.; Cheng, S.F.; Liou, S.W. A STROBE-compliant case-control study: Effects of cumulative doses of topical atropine on intraocular pressure and myopia progression. Medicine 2020, 99, e22745. [CrossRef] [PubMed]

56. Burstein, N.L. Preservative cytotoxic threshold for benzalkonium chloride and chlorhexidine digluconate in cat and rabbit corneas. Investig. Ophthalmol. Vis. Sci. 1980, 19, 308-313.

57. Wilson, W.S.; Duncan, A.J.; Jay, J.L. Effect of benzalkonium chloride on the stability of the precorneal tear film in rabbit and man. Br. J. Ophthalmol. 1975, 59, 667-669. [CrossRef]

58. Leopold, I.H. Local toxic effect of detergents on ocular structures. Arch. Ophthalmol. 1945, 34, 99-102. [CrossRef]

59. De Saint Jean, M.; Brignole, F.; Bringuier, A.F.; Bauchet, A.; Feldmann, G.; Baudouin, C. Effects of benzalkonium chloride on growth and survival of Chang conjunctival cells. Investig. Ophthalmol. Vis. Sci. 1999, 40, 619-630.

60. Cheng, J.; Yang, Y.; Kong, X.; Zeng, L.; Chen, Z.; Xu, J.; Chaoran, Z. The effect of 0.01\% atropine eye drops on the ocular surface in children for the control of myopia-The primary results from a six-month prospective study. Ther. Clin. Risk Manag. 2020, 16, 735-740. [CrossRef]

61. Cho, W.-H.; Fang, P.-C.; Yu, H.-J.; Lin, P.-W.; Huang, H.-M.; Kuo, M.-T. Analysis of tear film spatial instability for pediatric myopia under treatment. Sci. Rep. 2020, 10, 14789. [CrossRef] [PubMed]

62. Mirshahi, A.; Ponto, K.A.; Hoehn, R.; Zwiener, I.; Zeller, T.; Lackner, K.; Beutel, M.E.; Pfeiffer, N. Myopia and level of education results from the Gutenberg health study. Ophthalmology 2014, 121, 2047-2052. [CrossRef] [PubMed]

63. Schuster, A.K.; Krause, L.; Kuchenbäcker, C.; Prütz, F.; Elflein, H.M.; Pfeiffer, N.; Urschitz, M.S. Prävalenz von Kurzsichtigkeit und deren Veränderung bei Kindern und Ju-gendlichen. Dtsch Arztebl Int. 2020, 117, 855-860. [CrossRef]

64. Ziemssen, F.; Lagreze, W.; Voykov, B. Secondary diseases in high myopia. Ophthalmologe 2017, 114, 30-43. [CrossRef] [PubMed]

65. Tideman, J.W.L.; Polling, J.R.; Vingerling, J.R.; Jaddoe, V.W.V.; Williams, C.; Guggenheim, J.A.; Klaver, C.C.W. Axial length growth and the risk of developing myopia in European children. Acta Ophthalmol. 2018, 96, 301-309. [CrossRef]

66. Zhang, X.; Wang, Y.; Zhou, X.; Qu, X. Analysis of factors that may affect the effect of atropine 0.01\% on myopia control. Front. Pharmacol. 2020, 11, 01081. [CrossRef]

67. Mathis, U.; Ziemssen, F.; Schaeffel, F. Effects of a human VEGF antibody (Bevacizumab) on deprivation myopia and choroidal thickness in the chicken. Exp. Eye Res. 2014, 127, 161-169. [CrossRef]

68. McBrien, N.A.; Moghaddam, H.O.; Reeder, A.P. Atropine reduces experimental myopia and eye enlargement via a nonaccommodative mechanism. Investig. Ophthalmol. Vis. Sci. 1993, 34, 205-215.

69. Diether, S.; Schaeffel, F. Long-term changes in retinal contrast sensitivity in chicks from frosted occluders and drugs: Relations to myopia? Vis. Res. 1999, 39, 2499-2510. [CrossRef]

70. Carr, B.J.; Stell, W.K. Nitric oxide (NO) mediates the inhibition of form-deprivation myopia by atropine in chicks. Sci. Rep. 2016, 6, 9. [CrossRef] [PubMed]

71. Chiang, S.T.-H.; Turnbull, P.R.K.; Phillips, J.R. Additive effect of atropine eye drops and short-term retinal defocus on choroidal thickness in children with myopia. Sci. Rep. 2020, 10, 18130. [CrossRef] [PubMed]

72. Nickla, D.L.; Zhu, X.; Wallman, J. Effects of muscarinic agents on chick choroids in intact eyes and eyecups: Evidence for a muscarinic mechanism in choroidal thinning. Ophthalmic Physiol. Opt. 2013, 33, 245-256. [CrossRef] [PubMed]

73. Wallman, J.; Wildsoet, C.; Xu, A.; Gottlieb, M.D.; Nickla, D.L.; Marran, L.; Krebs, W.; Christensen, A.M. Moving the retina: Choroidal modulation of refractive state. Vis. Res. 1995, 35, 37-50. [CrossRef]

74. Read, S.A.; Fuss, J.A.; Vincent, S.J.; Collins, M.J.; Alonso-Caneiro, D. Choroidal changes in human myopia: Insights from optical coherence tomography imaging. Clin. Exp. Optom. 2019, 102, 270-285. [CrossRef] [PubMed]

75. Chrai, S.S.; Makoid, M.C.; Eriksen, S.P.; Robinson, J.R. Drop size and initial dosing frequency problems of topically applied ophthalmic drugs. J. Pharm. Sci. 1974, 63, 333-338. [CrossRef] [PubMed]

76. Pellinen, P.; Lokkila, J. Corneal penetration into rabbit aqueous humor is comparable between preserved and preservative-free tafluprost. Ophthalmic Res. 2009, 41, 118-122. [CrossRef] [PubMed]

77. Majumdar, S.; Hippalgaonkar, K.; Repka, M.A. Effect of chitosan, benzalkonium chloride and ethylenediaminetetraacetic acid on permeation of acyclovir across isolated rabbit cornea. Int. J. Pharm. 2008, 348, 175-178. [CrossRef] 
78. Tan, Q.; Ng, A.L.; Choy, B.N.; Cheng, G.P.; Woo, V.C.; Cho, P. One-year results of 0.01\% atropine with orthokeratology (AOK) study: A randomised clinical trial. Ophthalmic Physiol. Opt. 2020, 40, 557-566. [CrossRef]

79. Sánchez-González, J.-M.; De-Hita-Cantalejo, C.; Baustita-Llamas, M.-J.; Sánchez-González, M.C.; Capote-Puente, R. The combined effect of low-dose atropine with orthokeratology in pediatric myopia control: Review of the current treatment status for myopia. J. Clin. Med. 2020, 9, 2371. [CrossRef] 